\title{
The modern Buryat ethno-sphere: ethnicity and artistic culture
}

DOI: $10.31551 / 2410-2725-2018-4-2-289-301$

\section{Agomolonova Darima Dashievna}

Doctor of History, Assist.professor, Chief researcher of the Department of Philosophy, Cultural studies and Religion studies of The Institute for Mongolian, Buddhist and Tibetan Studies of the Siberian Branch of the Russian Academy of Sciences. Russia, 670047, Ulan-Ude, Sakhjyanova St., 6. E-mail: amog@inbox.ru

\begin{abstract}
The paper 'The modern Buryat ethno-sphere: ethnicity and artistic culture' proposes a new look at the phenomenon of ethno-sphere on materials of post soviet Buryatiya. In accordance with the socio-political processes in Russia for almost two decades, Buryat ethnicity is depoliticized but remains one of the principal social identities, which is currently manifested in cultural practices in particular. The author argues that the ideas of Buryat ethno-national revival and ethnic consolidation that were relevant for the period of ethnic mobilization (from the late 1980s to 2000) now find expression and embodiment in various fields of creativity - visual arts, prose and poetry, theater, music, and cinema. The artists are looking for new ways and forms, through which ethnic cultural traditions meet the aesthetic and ethical needs of contemporaries.
\end{abstract}

Key words: Buryats; ethno-sphere; artistic culture; collective memory; Buryat ideology; identity; cultural heritage.

\section{Қазіргі заманғы бурят этносферасы: этникалық және көркем мәдениет}

\section{Амоголонова Дарима Дашиевна}

тарих ғылымдарының докторы, доцент, РҒА СБ моңғолтану, буддология және тибетология Институтының жетекші ғылыми қызметкері. 670047, Улан-Удэ қ, ул. Сахьянова к, 6 үй. E-mail: amog@inbox.ru

\begin{abstract}
Аңдатпа. Мақалада посткеңестік Бурятия материалдары бойынша этносфера феноменіне жаңа көзқарас келтірілген. Ресей үшін соңғы екі онжылдықтың қоғамдық-саяси үдерістеріне сәйкес, Бурят ұлты саясиландырылуда, бірақ қазіргі кезде мәдени тәжірибеде көрініп тұрғандай негізгі әлеуметтік идентификациялардың бірі болып қала береді. Автор этникалық жаңару мен этникалық консолидация этникалық мобилизация кезеңінде белсенді (1980-шы жылдардың аяғынан бастап 2000 жылға дейін)деп көрсете келе, ол түрлі шығармашылық тұрғысынан іске асырылатынын дәлелдейді: бейнелеу өнерінде, проза мен поэзияда, театрда, музыкада, кинода, ал суретшілер этникалық мәдени дәстүрлердің замандастарының эстетикалық және этикалық қажеттіліктерін қанағаттандыратын жаңа жолдар мен формаларды іздейді.

Кілт сөздер: буряттар; этносфрера; көркем мәдениет; тарихи жады; бурят идеологиясы; бірегейлік; мәдени мұра.
\end{abstract}

\section{Современная бурятская этносфера: этничность и художественная культура}

\section{Амоголонова Дарима Дашиевна}

доктор исторических наук, доцент, ведущий научный сотрудник отдела философии, культурологии и религиоведения, Институт монголоведения, буддологии и тибетологии СО РАН. Российская Федерация, 670047 г. Улан-Удэ, ул. Сахьяновой, 6. E-mail: amog@inbox.ru

Абстракт. Статья представляет новый взгляд на френомен этносферы на материалах постсоветской Бурятии. В соответствии с общими для России социально-политическими процессами последних почти двух десятилетий, бурятская этничность деполитизируется, однако остается одной из основных социальных идентичностей, которая в настоящее время проявляется, например, в культурных практиках. Автор доказывает, что идеи этнонационального возрождения и этнической консолидации, актуальные для периода этнической мобилизации (с конца 1980-х до 2000 года), сейчас находят выражение и воплощение в различных областях творчества: в изобразительном искусстве, прозе и поэзии, театре, музыке, кино, а художники ищут новые пути и формы, благодаря которым этнические культурные традиции отвечают эстетическим и этическим запросам современников.

Ключевые слова: буряты; этноссрера; художественная культура; историческая память; бурятская идеология; идентичность; культурное наследие. 


\section{әОЖ/ УДк 73/76(571.54)}

\section{Современная бурятская этносфера: этничность и художественная культура ${ }^{1}$}

\section{Д.Д. Амоголонова}

Эпоха Перестройки способствовала этнизации художественного творчества, уже не скованного жестким предписанием быть «национальным по форме и социалистическим по содержанию». На протяжении двадцати лет успешно преодолевается ситуация в искусстве, о которой художник Алла Цыбикова писала следующее: «...на моей памяти не было ни одной выставки традиционного искусства. <...> живопись с 30-х годов у нас носит общероссийский характер <...>. В этом случае влияние России вряд ли было таким благотворным...» (Кореняко 2003: 91).

Преодоление мировоззренческой лакуны в сознании художников и через их посредничество среди рядовых зрителей является актуальной задачей бурятского культурного ренессанса, что отразилось в организационной деятельности Всебурятской Ассоциации Развития культуры (ВАРК), отметившей в 2016 г. свое 25-летие. Одна из задач организации была сформулирована как организация и проведение различных художественных мероприятий, развитие искусства, фольклора, народных традиций, праздников, состязаний и игр, создание кино- видеостудии «Бурят-Монголкино»². По инициативе ВАРК Народным Хуралом Республики Бурятия был принят Закон «О народных художественных промыслах в Республике Бурятия» (Закон № 529-ІІ от 4 декабря 2000 г.), составивший юридическую базу для возрождения традиционной материальной и духовной культуры этнических групп. Выступая на съезде ВАРК (2016 г.), спикер Народного Хурала Ц.-Д.Э. Доржиев в очередной раз определил назначение ВАРКа как содействие духовному единению и консолидации бурятского народа, проживающего в разных точках мира, а задачи организации сформулировал как сохранение этнической идентичности посредством поддержки бурятскому языку, возрождения традиций и обычаев, поскольку «только тогда мы сможем сохраниться как бурятский этнос» (ВАРК 2016).

Бурятское художественное творчество конца XX - начала XXI в., впрочем, равно, как и искусство предшествующего периода, представляет собой не только френомен культуры; в неменьшей степени оно является способом и системой, по выражению Ю.М. Лотмана, «обучения культуре», обусловленного структурой воспринимающего сознания, не противостоящего воспринимаемой системе: «Для культуры, которая представляет собой не только потенциальную информацию, заключенную в той или иной системе, но и реальную, извлеченную из нее тем или иным исторически данным коллективом, структура сознания, воспринимающая тексты, набор фрункциональных употреблений этих текстов не будет представлять нечто внешнее. Она будет составлять один из аспектов ее внутренней организации. Поэтому механизм введения системы в сознание коллектива, механизм "обу-

\footnotetext{
1 Работа выполнена в рамках государственного задания Федерального государственного бюджетного учреждения науки «Институт монголоведения, буддологии и тибетологии Сибирского отделения Российской академии наук (ИМБТ СО РАН)» по проекту XII.191.1.3. Комплексное исследование религиозно-фрилософских, историко-культурных, социально-политических аспектов буддизма в традиционных и современных контекстах России и стран Центральной и Восточной Азии, номер госрегистрации № AAAA-A17-117021310263-7 ("Comprehensive study on the religious, philosophical, historical, cultural, and sociopolitical aspects of Buddhism in the traditional and modern contexts of Russia, Central Asian and East Asian countries")

${ }^{2}$ Государственный Архив Республики Бурятия, Ф. Р-2091, Оп. 1, Д. 1, Л. 2.
} 
чения" не будет для культуры чем-то внешним» (Лотман 2001: 419).

В этом смысле постсоветское художественное творчество и для творца (xyдожника, писателя, поэта, композитора), и для «потребителя» «становится скрытой культурообразующей программой, оказывающей мощное воздействие на все вводимые в дальнейшем в сознание коллектива материалы. <...> Особенно значимым этот вопрос становится на стадии самосознания, когда культура выделяет из себя автомоделирующие тексты и вводит в свою память концепцию самой себя. Именно на этой стадии, прежде всего, возникает единство культуры» (Лотман 2001: 419).

В современном бурятском художественном творчестве (представленном, впрочем, не только бурятами) элементы дискурса этнической идентичности приобретают выпуклые черты; в нем прослеживается зримая связь с традицией (дихотомия) и одновременно - обусловленность современным состоянием общественного сознания. Порождаемое из собственных ресурсов художественное творчество (выступающее в качестве, по Лотману, автомодели культуры), оказывается той областью этнического, в которой обнаруживается наиболее эксплицитные и доступные пониманию знаки и символы, маркирующие этническое пространство и время. Таким образом создается единство хронотопа.

Несмотря на значительное разнообразие сюжетов и средств художественного выражения, существует устойчивый алгоритм преодоления осознаваемой художниками социалистического социального заказа и возвращения к национальным темам, связанным с коллективной историко-культурной памятью. Художественный дискурс становится важным фррагментом бурятской культурной этносферы как условно унифицированной картины мира, представляющей значимые и узнаваемые константы, среди которых следует в первую очередь назвать этнический образ, выступающий и как матрица художественного творчества, и как новое прочтение этнического текста. В таком качестве творчество имеет не только художественный смысл: посредством литературы, живописных, театральных, музыкальных и прочих произведений искусства преодолевается творческий и идентификационный кризис.

Можно сказать, что современное искусство как часть бурятского национального возрождения не только способствует восстановлению автомодели культуры: оно само представляет ее в зримых, узнаваемых и убедительных образах, слагаемых в сознании зрителя, читателя или слушателя в единство этнической культуры, становящейся «синхронно сбалансированной структурой» (Лотман 2001: 419).

Описывая этносфреру - систему знаков - посредством разнообразных образов, художественное творчество обогащает их символическими смыслами; преимущество такого представления заключается, прежде всего, в его одновременной универсальности и полисемантичности. При этом демократичность и общедоступность художественного творчества обеспечивают ему существенное преимущество по сравнению с научным или политическим дискурсом, поскольку потребитель, строящий свои оценки на эмоциях, не обязан обладать специальными знаниями и рационально объяснять свое отношение к произведению или его автору.

Вместе с тем, через символы, предположительно одинаково понимаемые носителями культуры, передается закодированная социально-значимая информация, служащая различным интегративным и воспитательным целям. Поэтому можно сказать, что художественные произведения одновременно являются фррагментом этносфреры, способом ее описания и даже вообще фрормой ее суще- 
ствования. Рассматривая этносфреру как одно из преломлений семиосферы, мы вправе определить ее значимость вслед за Ю.М. Лотманом: «Произведения искусства представляют собой чрезвычайно экономные, емкие, выгодно устроенные способы хранения и передачи информации. Некоторые весьма ценные свойства их уникальны и в других конденсаторах и передатчиках информации, созданных до сих пор человеком, не встречаются» (Лотман 2001: 9-10).

В процессе конструирования постсоветской идентичности художественная культура становится материальным свидетельством обновленной этничности и воплощением идеологем, освоенных и присвоенных общественным сознанием. Многообразие их художественных воплощений обуславливается творческим видением, манерой, опытом и целями творца, поэтому очень часто для художника сюжет является лишь отправной точкой для самовыражения, а собственно произведение рождается в большей степени благодаря эстетическим воззрениям автора, чем приверженностью традиции.

Отметим, что канон сохраняет значение непреложности в современной буддийской иконописи. В возрождении иконописи важное место занимает основанная известным художником Даши-Нимой Дугаровым школа-студия «Буряад зураг» (бурятская традиционная живопись), основанная в 1989 г., где студентов обучают рисованию буддийских танка минеральными красками.

Буддийские мотивы, иллюстрирующие преемственность буддийской традиции в Бурятии, присутствуют и в светской живописи, выполненной в традиционном стиле. Представителем этого направления является, к примеру, Лубсан Доржиев, придерживающийся традиционного стиля живописи. В иконографической манере выполнен портрет Агвана Доржиева, в стиле зураг - многие другие произведения художника: «Укрощение тигра Дугар Зайсаном», «Луу» (дракон), «Матарай толгой» (чудовище макара). Стиль традиционной бурятской орнаментики используется художником для изображения пейзажа (облаков, гор и земли) в картине «Домог» (Зеленый жеребенок), что «несет в себе духовность и веру» (Дашинимаева 2008: 8).

Сюжеты, к которым обращаются художники, с точки зрения специалистов могут выступать в качестве исторических, даже если речь идет о мифологических персонажах: «Не ослабевает интерес художников к национальной истории. Их обращение к таким образам как Гэсэр - у А.М. Миронова, Чингисхан - у И.Г. Налабардина, тотемные предки бурят - у Б. Доржиева, каждый раз приобретает новое звучание» (Баторова 2001: 10).

К исторической и эпической тематике обращаются и другие мастера художественного творчества: скульптор Александр Миронов (скульптуры «Гэсэр», «Джангар», «Всадник на коне»), художник Зоригто Доржиев (полотна «Спящий воин», «Телохранитель», «Купец», «Хэшэктэн», «Маленький воин»). В работах Даши Намдакова - широко известного в России и за рубежом бурятского скульптора по металлу - сплетаются национальные традиции и европейская пластическая классика. Произведения Даши Намдакова не подчинены канону, но несут в себе мироощущение художника, благодаря которому фольклорные, буддийские и шаманские идеи, зооморфные представления о стихиях и времени воплощаются в динамических фигурах реальных и франтастических персонажей «Царь-птица», «Конь Модэ», «Заан» (слон), «Ворон», «Стихия», «Буха-Найон» (первопредок), «Воспоминания о будущем». Осмысление образов традиционной культуры стало лейтмотивом творчества и другого скульптора - Баира Сундупова, который черпает вдохновение в идеях центрально-азиатского искусства, буддий- 
ской философрии, шаманского мировоззрения. Его работы - «Смерть кочевника», «Преображение Ямараджи», «Сvхэ-Баатар», «Ташаангуй (Страсть)», «Хоoһoн шанар (Аллегория)», «Хан Хэрдиг (Хан-Гаруда)», «Тахил (Подношение богам)» можно охарактеризовать как успешные попытки выразить традиционные сюжеты через современные пластические формы.

Свой собственный путь в творчестве нашел скульптор и ювелир-оружейник Жигжит Баясхаланов, работающий в Санкт-Петербурге. На его выставках со знаковыми названиями «Вперед к истокам» и «Сквозь стихию» представлены выполненные в бурятском традиционном стиле охотничьи ножи, интерьерные композиции и арт-объекты. Техника исполнения и художественный стиль старых мастеров соединяются в его творчестве с собственным мироощущением молодого художника, что дает оригинальный синтез традиции и современности. Свою манеру он называет «стилем силуэта»; в нем выполнены не только художественное оружие, но и скульптуры-ножны, такие как «Полководец» (воин в серебре рядом с монгольским знаменем-сульдэ), «Маленький воин» (мальчик в огромном шлеме и больших сапогах держит отцовский щит), «Маленькая невеста» (девочка, примеряющая традиционное свадебное убранство матери).

Масштабным проектом по возрождению буддийской литейной техники в России является художественная мастерская «Эрхим Дархан» (Искусный мастер), созданная при Иволгинском Дацане. Скульптуры Будды Шакьямуни, Ваджрасаттвы, Арьябалы, Пандито Хамбо Лама Даша Доржо Этигэлова - это религиозно-духовные объекты; одновременно они обладают высокими художественными достоинствами, а техника их исполнения связана с использованием новых технологий литья металлов.

По мотивам бурятского национального фольклора создан целый ряд театральных постановок. На фоольклорном материале строится спектакль «Свадебный круг, или Улейские девушки», поставленный на сцене БГАТД (авторы - Э.3. и С.Ц. Жамбаловы, режиссер-постановщик Д.Н. Баторова), в котором современная свадьба оказывается вовлеченной в мистические сюжеты западно-бурятских легенд. В заметке о спектакле театровед А.А. Политов, отмечая не только художественные достоинства, но и новаторские средства воплощения, пишет, что спектакль «впрямую связан с национальной культурной традицией, этноэкологическим комплексом представлений о связях Человека и Природы. В основе его сценически развитые элементы музыкально-песенного и мифопоэтического наследия бурят с западной стороны Байкала. <..> Зрители уносят впечатляюще цельный, обобщающий образ спектакля, его глубокую поэтически возвышенную атмосфреру и фрилософрскую содержательность» (Политов 2000: 8).

Интересным и тоже новаторским является спектакль «Поющая стрела» (театр кукол «Ульгер», режиссер Э.Б.-О. Жалцанов), основанный на бурятских сказках («В улус приезжает сказитель-улигершин и рассказывает народу легенду о старом и отважном Мээл-баторе, который один противостоял нашествию неприятельской орды во главе с заносчивым и жестоким Ээлэн Батором» (Программа 2005). Сохранив красоту и мудрость народной сказки, авторы сумели в полной мере адаптировать ее для восприятия современного юного зрителя. Постановочная, игровая и текстовая яркость способствовали тому, чтобы спектакль был тепло встречен не только в Улан-Удэ, но и в Москве, став в 2006 г. лауреатом премии «Золотая маска» (2006 г.) и войдя в репертуар Московского кукольного театра.

Крупным художественным событием в культурной жизни Бурятии стал спектакль «Угайм Сулдэ» (дух предков) (авторский коллектив: композитор Наран- 
баатар, хореографр-постановщик Дандар Бадлуев, аранжировщик Павел Карелов, художник Чингис Шенхоров); в основу спектакля положен песенный и танцевальный фольклор, мифология монголоязычных народов. Обычаи и традиции кочевой цивилизации передаются посредством современной хореографии и музыкального сопровождения. О спектакле и о целях его создания Д.Ж. Бадлуев сказал так: «Мы консультировались с учеными, этнографами, философрами. В основе - сюжеты древних легенд, в характере танцев, песен - мироощущение кочевого народа. Стихия, в которую погружается зритель, дает сильнейшую энергетику. Думаю, что в какой-то степени можно ощутить дыхание прошлого времени, изучить историю наших предков и открыть для себя новое измерение к жизни» (Мудрая сила «Байкала» 2005: 20).

Фольклорные сюжеты легли в основу и других спектаклей. Одноактный балет «Легенда о птице Муу-Шубун» (по пьесе драматурга Нелли Матхановой, балетмейстер-постановщик Вячеслав Донгак) повествует о любви дочери шамана Сараны и хорошего доброго парня Галсана. Шаман желает, чтобы дочь стала шаманкой, и в гневе насылает на нее три проклятия. Девушка превратилась в птицу Муу-Шубун, которая охотится за юношами и убивает их, высасывая душу и мозг. Галсан в поисках любимой попадает в хоровод-ехор темных сил. И хотя история заканчивается победой Муу-Шубун, она возвращает Галсану его хадак-душу. Рассказывая о сложной задаче, стоявшей перед авторами спектакля, В. Донгак отметил: «Казалось абсолютно невозможным рассказать такую красивую, большую легенду за сорок минут в одноактном балете. <..> Спектакль не классический, не модерн и не джаз-балет. Это совсем другой жанр, где элементы театра пластики переплетаются с народными традициями» (Иванова 2000: 5). Таким образом, и этот спектакль представляет собой синтез традиционного фольклорного сюжета с выразительными средствами и принципами современного балетного искусства. То же можно сказать и о театрализованном концерте «Ода МатериЛебеди» (театр танца «Бадма Сэсэг», художественный руководитель Д.Ж. Бадлуев), в котором даже представлена реконструкция шаманского обряда - путешествия шамана по нижнему, среднему и верхнему мирам.

Этот спектакль является ярким примером того, что во многих, если не во всех, случаях воплощения идей и образов шаманизма выполняется (наряду с художественными задачами) обучающая фуункция культуры. Например, для подготовки концерта «Ода Матери-Лебеди» Дандар Бадлуев, поставивший перед собой цель поставить достоверное действо, «перелистал сотни журналов и книг, ездил в фольклорные экспедиции, познакомился с почтенными старцами, не раз бывал в музеях, чтобы детально изучить покрой традиционной бурятской одежды разных местностей, в том числе одежду кочевых племен. Конечно, это еще не предел. Этнография - наука, не терпящая торопливого, поверхностного изучения» (Гончикова 2002: 8). В том же спектакле в танце достаточно достоверно изображается шаманский ритуал: «Праздник в честь МатериЛебеди продолжается, чтобы к полудню завершиться. Вместе с яркими лучами хори-буряты и хонгодоры простятся со своим тотемом до следующего тайлгана. Но сначала поднесут Матери-Лебеди белый хадак, и каждый из них унесет к себе домой кусочек освященного уголька, чтобы укрепить свой очаг» (там же).

На сцене Бурятского театра оперы и балета поставлена национальная опера в трех действиях «Гэсэр» (композитор А.А. Андреев, режиссер-постановщик Ц.Д. Бальжанов), в которой заглавный герой предстает в бурятской и монголь- 
ской версии эпоса: как культурный герой, очищающий землю от чудовищ и таким образом осуществляющий цивилизаторскую деятельность.

Бурятский шаманизм, занимавший видное место в бурятской идеологии периода этнической мобилизации в качестве исконной религии, стал важным объектом в художественном воплощении образов возрожденной этнокультурной памяти. Например, на выставке «Шаманские тропы» в Музее истории Бурятии художники представили работы, изображающие шаманов и шаманские ритуалы (Чингис Мандаганов - «Обряд», «Шаманка», «Охотник»; Евгений Болсобоев - «Таежник», «Камлание»), а также шаманскую космологию в визуально-художественном воплощении. Картины Е. Болсобоева на тему священных деревьев («Священная сосна» и «Священная береза») вдохновлены мифологическими представлениями о верхнем, нижнем и среднем мирах; деревья при этом, с одной стороны, символизируют эти миры (крона, ствол и корни), являясь зримым воплощением axis mundi, a с другой стороны, представляют путь шамана, который способен посещать любой из миров. На полотне «Замби тиб» (путешествие по мирам) художник изобразил трехчленное вертикальное деление пространства, центром которого является пронизывающий все три уровня шаман на лошади. Отметим, что средний мир, в котором изображены люди, животные, рыбы и деревья, содержит и стилизованно написанный автомобиль как маркер современности. Космологическая тема присутствует и в картине «Шаманская береза», где ветви дерева - это три уровня мира. На картине Чингиса Мандаганова «Новолуние» проявляется тот же космологический мотив трехчастного мира, а в работах «Элинсэр эсэге» (Дух предков), «Буурал Баабай» (Седые предки), «Бургэд Шубуун ноен» (Хан Беркут) изображены персонажи шаманской мифологии.

Интересным и красочным примером приобщения детей к традиционной культуре является книга для детей «Алмазная книга о бурятах», написанная и проиллюстрированная художницей В.П. Алагуевой. Преследуя просветительские цели, автор, как и Е. Болсобоев и Ч. Мандаганов, а тоже показывает вертикальную трехчастную шаманскую космологию, а в тексте поясняет: «Верхний мир - Небеса. Владыка Солнце. Средний мир - Земля. Владычица Этуген. Нижний мир Подводное и Подземное Царства. Владыка Уса Лосон» (Алагуева 2007: 76). В. Алагуева представляет сложный мир бурятской культуры с позиций сформировавшегося и непротиворечиво существующего в общественном сознании единства буддийских и шаманских идей. Духи и хозяева местности (Владыка Байкала, Хозяйка Ангары) соседствуют на страницах книги с Буддой и Бодхисаттвами («Будда всегда смотрит за своими детьми, посылая им свою любовь» (Алагуева 2007: 81), а также с персонажем христианской религии архангелом Михаилом, называемым равным Богу и Ваджрадхарой (Алагуева 2007: 64).

Особое место в национальном художественном дискурсе отводится образу Чингис-хана. К примеру, ему и созданной им империи посвящена книга Ялбака Халбая (Борис Халбаев) «Чингис-хан - гений» (Халбай 2001). Это скорее художественное, чем научное или научно-публицистическое, произведение является результатом желания автора выразить Великому Предку свое восхищение и заразить этим настроением читателей. Название книги, приуроченной к знаменательным датам, широко праздновавшимся в Монголии, вполне отражает ее содержание: Чингис-хан изображается как гениальный полководец, государственный деятель и гуманист, как миротворец и провидец, поэтому в целом произведению свойственен возвышенно-эпический 
стиль. А деятельность Чингис-хана характеризуется так: «Руководство монгольского народа в XIII веке было самым передовым на планете. <...> Гениальный Чингис-хан предложил своему народу четкие, сильные и строгие законы-ясы. <...> Большинство диковатых народов планеты получили урок благородства в таких тонких сферах (имеется в виду сфера международных отношений - Д.А.) впервые только от монголов, которых смело можно считать основоположниками современной дипломатии. <..> Монголы впервые в мире построили государство, в котором существовали самая минимальная разница между богатыми и бедными, а также налог в пользу нищих, вдов и сирот. <..> Монголы в XIII веке не обладали распутными наклонностями, любили чистоту, естественность и строгость нравов, отвергали роскошь и во всем следовали умеренности. <...> Вывод: мораль и эти составляющие общей культуры монголов стояли на более высокой ступени развития, чем у всех завоеванных народов. <...> Более гуманных завоевателей и правителей-чужеземцев история человечества не знает. <...> Чингис-хан - самое святое, что есть у всех монголоязычных народов» (Халбай 2001: 267-290).

Важное место, которое отведено Чингис-хану и его времени в современном дискурсе бурятской этничности, воодушевило театральную общественность воплотить его образ в сценическом искусстве. Еще в девяностые годы режиссер Ц.Д. Бальжанов осуществил масштабную постановку пьесы о Чингис-хане «По велению Вечно Синего Неба» в Калмыкии. Вернувшись в Улан-Удэ, режиссер поставил «Чингис-хана» (автор пьесы - Булат Гаврилов) на сцене бурятского драматического театра. Спектакль был показан также и в Монголии, где актер Георгий Бутуханов за роль Чингис-Богдо-Хана получил от правительства орден Чингис-хана.

Посредством апеллирования к образу Чингис-хана, являющемуся коллективной этнической ценностью, авторы акцентируют философско-этические проблемы, более значимые для современников: «Неужели человек, перенесший такое глумление над собой, не попытается избавить от подобного произвола своих родных, свой род и племя, весь мир?! (Васильева 2001: 12)

В таком же контексте современного мировидения образ Чингис-хана выступает в живописном полотне художника Иннокентия Налабардина - триптихе «Из глубины веков» («Мать Чингис-хана», «Чингис-хан», «Чингис-хан в Средней Азии»). Триптих И. Налабардина, несмотря на реалистическую манеру письма, настраивает на возвышенное восприятие, «предлагая зрителю самостоятельно воспроизвести дальнейшую хронику событий того эпического времени. И хотя в двух боковых частях триптиха не обозначен зримый образ Чингис-хана, его сакральное влияние присутствует в самой ауре происходящих действий, композиционно слитых с центральным изображением» (Пазников 2001: 10) (центральная часть изображает гигантский поясной портрет Чингис-хана над его войском).

Тема Чингис-хана в не меньшей степени вдохновила художников, работающих в иных сферах культуры. Например, Алексей Гатапов написал повесть «Первый нукер Чингис-хана», легший в основу одноименного фильма (авторы сценария - С. Жамбалов и Э. Жалцанов, режиссер - Э. Жалцанов), называемого «первым бурятским фильмом». Рассказанная с экрана история знакомства молодого Тэмуджина с Боорчу, ставшим его верным другом и сподвижником, вызвала огромный интерес во всей этнической Бурятии. Этот фильм планировался как начало многосерийной киноэпопеи «Люди длинной воли», посвященной соратникам Чингис-хана, таким как полководцы Джэбе и Субэдэй. Актуаль- 
ность темы и причины большого интереса к «Первому нукеру» еще на стадии съемок разъясняет журналист Ешигма Цыбенова: «Люди длинной воли - это наша с вами история» (Цыбенова 2005: 2).

Тема родной земли является, конечно, одной из самых важных для мастеров художественного творчества. Поэтесса Галина Раднаева выражает свое мировидение через чувство духовно-исторического родства: «Но, ухо к сердцу Азии прижав,/ Я слышала не стук ее сердечка,/ А то, как над седою тишью трав / Позвякивает на коне уздечка» (цит. по: Дампилова 2007a: 103). Возрождая в своем творчестве образы культурной памяти, поэтесса устанавливает связь между настоящим и эпическим временем: «Я чувствую, что я - всегда в седле, / Что отблеск битв Гэсэра - на челе, / Что в воинстве его была и буду!» (цит. по: Дампилова 2007a: 30); «И тень Гэсэра, может, потому / Обходит неустанно жизнь веками,/ Чтобы убедиться: в каждом ли дому / Горит огонь, зажженный смельчаками» (цит. по: Дампилова 2007a: 21).

Литературовед Л.С. Дампилова очень точно охарактеризовала особенность современной бурятской поэзии (хотя писала она конкретно о поэте Баире Дугарове): «Использование мифологического и исторического материала в качестве реминисценций выступает главной формой художественного обращения к прошлому», а образы, «индивидуально переосмысленные, являются "коллективной памятью" нации» (Дампилова 2007б: 6). У Баира Дугарова имя Чингис-хана становится поэтическим тропом, способствующим передаче настроения возвращенной памяти:

Я прошел по путям, где промчались монгольские кони, на Восток и на Запад до Хуанхэ и Балкан.

Проступали огни небоскребов на облачном фоне, и глядел мне вослед сквозь столетия сам Чингис-хан.
Не по воле высокого

Вечного Синего Неба по желанию сердца

и тайному зову крови привела меня память, сама отряхаясь от пепла, на просторы моей родословной тоски и любви (Дугаров 2007: 89).

На тему сохранения бурятского языка, широко обсуждаемую в дискурсе этнокультурного возрождения, поэт Б.С. Дугаров откликнулся в СМИ: «С тем, что умирает бурятский язык, мне как буряту трудно смириться. С исчезновением языка уходит самая сокровенная часть самоидентификации нации. Проблему нужно решать властям. Ведь сейчас иностранцы изучают бурятский язык с особым рвением, а наши чиновники и в ус не дуют. Жаль, что у городских бурятов самосознание явно подводит. Они не знают свой язык, так что они не буряты, а суррогат бурятов» (Мнение экспертов 2008: 5). А в поэтическом творчестве поэт, пишущий в основном на русском языке, высказывает сходное суждение так: «Рекой, распавшейся на рукава, / монгольские распались языки. / От общего истока далеки, / они текут, храня черты родства. / <.. > Язык отцов, прости за немоту, / прости, и к горлу подступает ком. / Утраченного дара красоту / на языке восполню ли другом?!» (Дугаров 2007: 138).

Призыв к сохранению и возрождению бурятского языка - одного из самых значимых фррагментов этносферы (и необходимого, по мнению идеологов, ус- 
ловия сохранения этноса) - нашел поэтическое выражение в творчестве другого поэта, Есугея Сындуева:

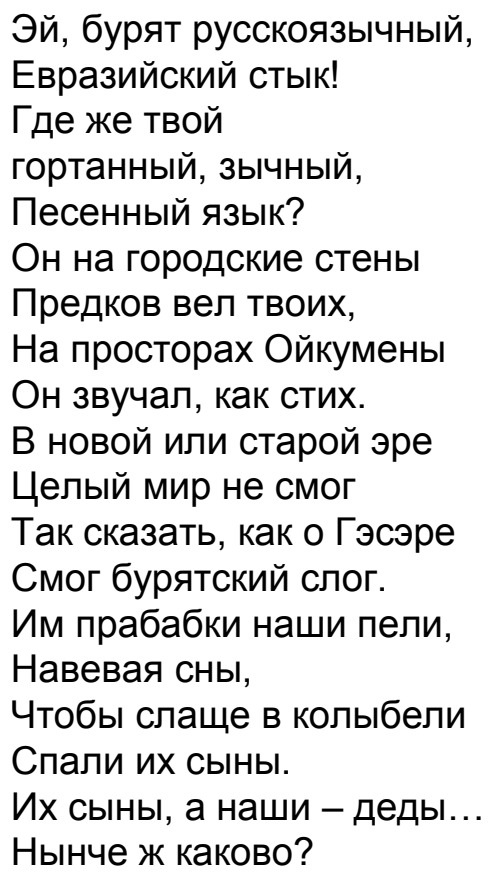

Скоро лишь языковеды

Будут знать его.

Без него на белом свете

Ты и бос, и гол.

За него лишь ты в ответе,

Ты, бурят-монгол!

Если всем нам дружно

взяться,

Мы его вернем,

Чтоб ему в любви

признаться

ты сумел на нем.

Чтобы был ты

двуязычный,

Чтобы не отвык

Прославлять гортанный,

зычный,

Песенный язык (Сындуев 2005: 14).

Таким образом, характерной чертой бурятского художественного творчества постсоветского периода является этнонациональная тематика, причем культурно-художественные процессы отразили темы, лозунги и этапы постсоветской национальной идеологии. Эти этапы мы предлагаем рассматривать хронологически, но ни в коем случае не подразумеваем их раздельность: 19901995 гг. - политизация этнокультурных процессов; 1996-2000 гг. - широкое обсуждение бурятской этнокультурной проблематики в научных и публицистических работах, изменение социальных функций религии, обращение к историческому наследию в художественном творчестве с одновременным угасанием политического компонента идеологии; с 2000 г. по настоящее время - установление и функционирование обратной связи между выработанной элитами идеологией и ментальностью представителей бурятской общности, способствующей деполитизации этнокультурных процессов. Условное деление предпринимается лишь с операционной целью, при этом мы полагаем, что каждый последующий этап неотделим из предыдущего и системно от него зависит.

Фестиваль «1000-летие эпоса Гэсэр» (1991-1995 гг.), проходивший на всей территории этнической Бурятии и призванный символизировать единство бурятского народа, стал практическим воплощением первого этапа национального возрождения. О том же свидетельствовали художественные мероприятия в связи с признанием нового года по лунному календарю (Сагаалган) в качестве официального праздника. Для художественных произведений и культурных мероприятий второго этапа характерны усилия по включению исторического национального наследия в современность, вследствие чего фольклор становится не просто областью традиции, а живой и актуальной частью этнического мировоззрения и практик. Существенно возрос статус национальных массовых культурных мероприятий. Так, летний спортивный праздник Сурхарбан, ранее про- 
водившийся только на улан-удэнском ипподроме, теперь стал общереспубликанским мероприятием, нацеленным на «формирование и распространение идей духовного единства, национального согласия этноса, воспитание подрастающего поколения и молодежи на основе многовековых традиций народной культуры», причем апофреозом праздника теперь являются торжественные мероприятия на площади Советов г. Улан-Удэ.

Третий этап этнической идеологии, начало которого мы относим к 2000 г., характеризуется установлением прочной обратной связи между этнической идеологией и художественными феноменами. Темы, которым посвящают свое творчество деятели культуры, являются неполитической интерпретацией национальной идеологии и потому затрагивают большинство социальнозначимых для бурят ценностей. Это касается отражения в искусстве сюжетов, связанных с реальной и мифологической историей, буддизмом и шаманизмом.

На протяжении длительного периода формируется пространство этносфреры, основывающееся на традиции, но развивающееся в принципиально иных исторических и мировоззренческих условиях. Благодаря включенности жителей Бурятии в современные процессы России и мира, обращение к историческим и культурным ценностям не порождает архаизации ни в одной области общественных практик, однако упрочивает этносфреру как социальную (социокультурную) систему. Ее элементы - подсистемы - составляют неразделимую совокупность взаимозависимых фрагментов: политическая и культурная история (как относящаяся к отдаленному прошлому, так и современная), образы историко-культурной памяти, традиционный фольклор, религия, этнический язык, художественная культура, включающая литературу, драматургию, живопись, скульптуру, музыку, кино, различные фрормы театрального искусства. Парадигмы этничности, сформулированные в годы этнической мобилизации, продолжают воспроизводиться в рамках дискурса, который, благодаря своему неполитическому содержанию и следующей из этого факта бесконфлликтности, становится все более популярным, т.е. охватывающим каждого, ощущающего свою сопричастность этнической культуре. Более того, благодаря элиминированию этнополитического разграничения, формируется надэтническая культурная идентичность, характеризующаяся тем, что свою сопричастность к бурятской культуре (в первую очередь, к некоторым народным обычаям) испытывают и не-буряты, что способствует укреплению региональной идентичности.

Примеры современного бурятского художественного творчества доказывают, что оно является не только фрормой включения в этнонациональное возрождение. Оно способно на любом историческом отрезке и при любом (или почти любом) политическом климате представить символы, убеждающие в наличии этнокультурного пространства. Процессы в сфрере современной художественной культуры представляют собой конкретные проявления феномена обратной связи между этнонациональной идеологией и этнокультурными практиками, при этом деятели литературы и искусств вносят реальный вклад в деполитизацию этничности.

\section{Әдебиеттер тізімі / Список литературы}

1. Алагуева В.П. Алмазная книга о бурятах. - Улан-Удэ: «Республиканская типография», 2007.

2. Баторова Е. Все познается в сравнении // Бурятия. - 2001. - 16 мая. - С. 10

3. Васильева А. «Чингис-хан»: в ожидании чуда... // Правда Бурятии. - 2001. - 8 июня. - С.12.

4. Всебурятская ассоциация развития культуры выбрала своего нового председателя [Электронный ресурс] // Сетевое издание «Информационное агентство Буряад Унэн». - 2016. - 01 ию- 
ля. - URL: www.burunen.ru/site/news?id=11882. (Дата обращения: 11.05.2018).

5. Гончикова Н. «Бадма Сэсэг» поет оду Матери-Лебеди» // Бурятия. 2002. - 24 января. - С. 8.

6. Дампилова Л.С. Поэтика лирики Галины Раднаевой. - Улан-Удэ: Изд-во «Бэлиг», 2007.

7. Дампилова Л.С. Предисловие «Когда мне не хватает неба...» // Дугаров Б.С. Струна земли и неба. Стихотворения. - Улан-удэ: Изд-во «Республиканская типография», 2007. - С. 3-7.

8. Дашинимаева М. Лубсан Доржиев - уникальное явление в бурятской живописи // Бурятия. 2008. - 21 февраля. - С. 8.

9. Дугаров Б.С. Струна земли и неба. Стихотворения. - Улан-удэ: Изд-во «Республиканская типография», 2007.

10. Иванова Л. «Легенда о птице Муу-Шубун» // Правда Бурятии. - 2000. - 11 июля. - С. 5.

11. К Кореняко В.А. Альбина Цыбикова - художник и друг // Вестник Евразии. - 2000. - № (21). - С. 42-106.

12. Лотман Ю.М. Семиосфера. - СПб: «Искусство - СПБ», 2001.

13. Мнение экспертов // Аргументы и Факты в Бурятии. - 2008. - № 21. - С. 5.

14. Мудрая сила «Байкала» // Мой любимый Улан-Удэ. - 2005. - Спецвыпуск газеты, посвящ.

339-летию г. Улан-Удэ.

15. Пазников О. Зримый образ // Правда Бурятии. - 2001. - 11 мая. - С. 10.

16. Политов А. Сказание о земных и неземных небесных девах // Бурятия. - 2000. - 16 ноября. - С. 8.

17. Программа I кочевого Международного театрального фестиваля «Желанный берег». - УланУдэ, 2005.

18. Сындуев Е. Песенный язык // Правда Бурятии. - 2005. - 3 ноября. - С. 14.

19. Халбай Я. Чингис-хан - гений. -Улан-Удэ: Издательство ОАО «Республиканская типография», 2001.

20. Ц Цыбенова Е. Великий воитель: история знакомства с Боорчу // Бурятия. - 2005. - 5 августа. - С. 2.

\section{Reference}

Alagueva 2007 - Alagueva, VP 2007, Almaznaya kniga o buryatah, Izd-vo OAO «Respublikanskaya tipografiya», Ulan-Ude. (Alagueva, VP 2007, The Diamond Book about Buryats, Izd-vo OAO «Respublikanskaya tipografiya», Ulan-Ude). (in Rus).

Batorova 2001 - Batorova, E 2001, Vse poznaetsya v sravnenii, Buryatia, May 16, S. 10. (Batorova, E 2001, Everything is learned in comparison, Buryatia, May 16, S. 10). (in Rus).

Cybenova 2005 - Cybenova, E 2005, Velikii voitel': istoriya znakomstva s Boorchu, Buryatia. August 5, S. 2. (Cybenova, E 2005, The Great Warrior: The story of acquaintance with Borchoo, Buryatia. August 5, S. 2). (in Rus).

Dampilova 2007 - Dampilova, LS 2007, Poetika liriki Galiny Radnaevoi, Izd-vo Belig, Ulan-Ude. (Dampilova, LS 2007, The poetics of Galina Radnaeva's lyrics, Izd-vo Belig, Ulan-Ude). (in Rus).

Dampilova 2007 - Dampilova, LS 2007, Predislovie "Kogda mne ne hvataet neba...", Struna zemli $i$ neba. Stihotvoreniya, Izd-vo "Respublikanskaya tipografiya", Ulan-ude, P. 3-7. (Dampilova, LS 2007, Foreword "When I miss the sky ..., Struna zemli $i$ neba. Stihotvoreniya, Izd-vo "Respublikanskaya tipografiya", Ulan-ude, P. 3-7). (in Rus).

Dashinimaeva 2008 - Dashinimaeva, M 2008, Lubsan Dorzhiev - unikal'noe yavlenie v buryatskoi zhivopisi, Buryatiya, Fabruary 21, S. 8 (Dashinimaeva, M 2008, Lubsan Dorzhiev - a unique phenomenon in Buryat painting, Buryatiya, Fabruary 21, S. 8). (in Rus).

Dugarov 2007 - Dugarov, BS 2007, Struna zemli i neba. Stihotvoreniya, Izd-vo «Respublikanskaya tipografiya», Ulan-Ude. (Dugarov, BS 2007, String of earth and sky. Poems, Izd-vo «Respublikanskaya tipografiya», Ulan-Ude). (in Rus).

Gonchikova 2002 - Gonchikova, N 2002, "Badma Seseg" poet odu Materi-Lebedi», Buryatia, January 24, S. 8. (Gonchikova, N 2002, "Badma Seseg" is singing an ode to Mother-Swan, Buryatia, January 24, P. 8 ). (in Rus).

Halbai 2001 - Halbai, Ya 2001, Chingis-han - genii, Izdatel'stvo OAO "Respublikanskaya tipografiya”, Ulan-Ude. (Chinggis khan the genius, Izdatel'stvo OAO "Respublikanskaya tipografiya", Ulan-Ude). (in Rus).

Ivanova 2000 - Ivanova, L 2000, "Legenda o ptice Muu-Shubun», Pravda Buryatii, July 11, S. 5. (Ivanova, L 2000, «The legend of the Muu-Shubun bird», Pravda Buryatii, July 11, S. 5). (in Rus).

Korenyako 2003 - Korenyako, VA 2003, Al'bina Cybikova - hudozhnik i drug, Vestnik Evrazii, N3(21), S. 42-106. (Korenyako, VA 2003, Al'bina Cybikova - the artist and the friend, Vestnik Evrazii, N3(21), S. 42-106). (in Rus).

Lotman 2001 - Lotman, YuM 2001, Semiosfera, Iskusstvo, Saint-Petersburg. (Lotman, YuM 2001, Semiosphere, Iskusstvo, Saint-Petersburg). (in Rus).

Mnenie ekspertov 2008 - Mnenie ekspertov, Arguments and Facts in Buryatia 2008, N21. S. 5. (Mnenie ekspertov, Arguments and Facts in Buryatia 2008, N21. S. 5). (in Rus).

Mudraya sila "Baikala" 2005 - Mudraya sila "Baikala", Moi lyubimyi gorod. Spec. vyp, posvyash. 339letiyu g. Ulan-Ude, g. Ulan-Ude, S. 20. (Wise power of "Baikal", Moi lyubimyi gorod. Spec. vyp, posvyash. 339-letiyu g. Ulan-Ude, g. Ulan-Ude, S. 20). (in Rus).

Paznikov 2001 - Paznikov, O 2001, Zrimyi obraz, Pravda Buryatii, 11 maya, S. 10. (Paznikov, O 2001, 
Visible image, Pravda Buryatii, 11 maya, P. 10). (in Rus).

Politov 2001 - Politov, A 2000, Skazanie o zemnyh i nezemnyh nebesnyh devah, Buryatia, November 16. S. 8. (Politov, A 2000, A Legend about terrestrial and unearthly heavenly maidens, Buryatia, November 16. P. 8). (in Rus).

Programma I kochevogo 2005 - Programma I kochevogo Mezhdunarodnogo teatral'nogo festivalya "Zhelannyi bereg" 2005, Ulan-Ude. (Program of the first nomadic International theatrical festival "Desired shore" 2005, Ulan-Ude). (in Rus).

Synduev 2005 - Synduev, E 2005, Pesennyi yazyk, Pravda Buryatii, November 3, S. 14. (Synduev, E 2005, Song language, Pravda Buryatii, November 3, S. 14). (in Rus).

Vasil'eva 2001 - Vasil'eva, A 2001, "Chinggis-khan": v ozhidanii chuda, Pravda Buryatii, June 8, S.12. (Vasil'eva, A 2001, Chinggis-khan: waiting for a miracle, Pravda Buryatii, June 8, S.12). (in Rus).

Vseburyatskaya associaciya razvitiya 2016 - Vseburjatskaja associacija razvitija kul'tury vybrala svoego novogo predsedatelja, Setevoe izdanie «Informacionnoe agentstvo Burjaad Unjen» 2016, 01 ijulja, retrivied 11 of May, $2018<w w w . b u r u n e n . r u / s i t e / n e w s ? i d=11882>$. (The All-Buryat Association for development of culture has chosen its chairman, Setevoe izdanie «Informacionnoe agentstvo Burjaad Unjen» 2016, 01 ijulja, retrivied 11 of May, 2018 <www.burunen.ru/site/news?id=11882>). (in Rus). 